\title{
Design and Implementation of a Subject Librarian Training Program for University Libraries in China
}

Based upon the subject librarian training practice of CALIS Phase III "Librarian Literacy Training and Qualification Certification" in the charge of Shanghai Jiao Tong University Library, this paper elaborates upon a design for a subject librarian training system concerning objectives, methods, courses, tests, organization and management mechanisms. From November 2010 to December 2011, the program has held four phases of liaison librarian training respectively and trained 322 liaisons for 197 universities in China. Additionally, it analyzes major characteristics of the training program and points out what we should note in the training process in order to achieve success in the implementation of subject librarian training.

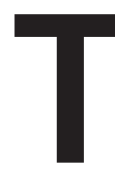

he expected competencies of subject librarians, key elements in determining effectiveness of library subject services, not only reflect a librarian's collection development skills and service innovation abilities but also have an impact on the transition of library service models. Due to the present urgent need for innovation in library services and the enhancement of subject librarian capacities, the CALIS (China Academic Library \& Information System) Program Phase III regards subject librarian training as a vital part of "Librarian Information Literacy Training and Qualification Certification". Through implementation of five phases of subject librarian training, the CALIS Program plans to cultivate a group of subject librarians with practical abilities and innovative spirit for Chinese university libraries and hence promote the development of librarianship in China.
In this paper, the authors look at subject librarian training programs in China, in an effort to increase librarian training program directors, managers, and organizers' knowledge of librarian training in the world and further improve liaison librarians' abilities.

\section{LITERATURE REVIEW}

The demand for subject specialists has created new levels of responsibility for reference librarians. The assigned responsibilities such as "editing websites, designing resource navigations, and creating subject blogs," indicate the need for subject librarians to keep up with current information technology skills in addition to maintaining traditional librarianship skills. ${ }^{1}$ Results of a survey of New Zealand academic subject librarians conducted in mid-2011 show that serving academic library

\section{Jing Guo, Qinling Huang, and Xiaobin Lu}

Correspondence should be addressed to Xiaobin Lu (luxb@ruc.edu.cn), Professor, Doctorate Supervisor and Associate Dean of School of Information Resources Management, Renmin University of China.

Jing Guo is a deputy director of Shanghai Jiao Tong University Library.

Qinling Huang is a subject librarian of Shanghai Jiao Tong University Library.

The authors would like to express sincere gratitude to The Key Research Project of Chinese Fund for the Humanities and Social Sciences: Research on Information Resource Integration and Service under the Environment of Cloud Computing" (Grant No. 12\&ZD220). Besides, we would like to express our cordial thanks to the editors, reviewers, and colleagues who have given many valuable suggestions to the paper.

Reference \& User Services Quarterly, vol. 54, no. 2, pp. 43-51

(c) 2014 American Library Association. All rights reserved.

Permission granted to reproduce for nonprofit, educational use. 


\section{FEATURE}

customers requires not only traditional "reference" skills, but also skills that reflect adaptability, strong communication, customer service, technology support, and training. ${ }^{2}$ Librarians at George Mason University Library further put forward that the basic qualities a competent librarian is expected to have should include: "commitment to developing, providing and maintaining high quality services and programs, valuing knowledge, and life-long learning, fostering collaboration and teamwork, engagement in professional development, an enterprising spirit reflecting flexibility, adaptability, intellectual curiosity, creativity, initiative, persistence, excellent communication and instructional skills, time management and organizational skills." 3 These features summarize the required capabilities of liaison librarians well.

Due to stringent requirements set for subject librarians, many professionals stress librarian literacy training. Krasulski gives some advice, including ways the access services community can act to fill the gap left by the absence of training opportunities in library and information science graduate programs. ${ }^{4}$ Luo's study suggests content design opportunities for text reference training and education to help improve service performance. ${ }^{5}$ Cassella et al. point out that academic programs should be developed to include communication, project management, and team work skills and lay more emphasis on copyright issues. The study also indicates that repository managers will have to spend a lot of time on professional training and self-directed learning. ${ }^{6}$ Todorinova et al. review standards for reference training in academic libraries with a focus on "one-desk service points" and think about best practices for planning, implementing, and evaluating training programs for librarians. ${ }^{7}$

China, however, lacks professional qualification certificate systems for librarians and pertinent and systematic librarian training programs as well. In comparison with United States and United Kingdom university libraries, both the qualification requirements of the occupation and the subject service content in China's university libraries are "left behind." Many university librarians in China do not have library school education or librarian information literacy training, and this influences their ability to offer high quality subject services. ${ }^{9}$ The libraries lack talented liaisons with strong academic backgrounds, advanced professional proficiency, and rapid adaptability. According to a survey of 62 librarians coming from 34 university libraries located in different regions of China participating in Project 985 (a project for funding world-class universities in the 21 st century conducted by the government of the People's Republic of China), 65 percent of the librarians have less than two years work experience in subject services, despite the fact 69 percent of them are subject liaisons. These statistics show that even in Project 985 university libraries, subject service is still in the exploratory stage and the capacity of subject librarians needs to be improved by integrated and systematic training with innovative ideas, novel approaches, and advanced technologies. Since 2000, libraries have made efforts to improve human resources management. In some key universities, librarians are employed on a "relatively competitive basis", yet "the percentage of librarians with Master and Doctoral degrees" is not so high. ${ }^{10}$ In 2011, CALIS III Librarian Literacy Training and Qualification Certification Program, a vital executive program, was carried out and made great achievements. But the training still needs to be improved regarding the schedules, teaching atmosphere, training forms, training content, etc., to "enhance the subject librarians' ability, raise the service standards, and promote the quick and sound development of librarianship in China." 11 In 2002, the first "National Workshop for Information Literacy in Higher Education" was carried out, and it "attracted" nearly 170 librarians from different universities. ${ }^{12}$ Although various related, prevalent, and popular librarian training has been gradually carried out in recent years, there is still a shortage of systematic training programs for subject librarians in Chinese university libraries. ${ }^{13}$ The government, university officials, and libraries, as well as society, should commit to "promot[ing] librarianship and build[ing] a powerful librarian workforce," to satisfy the needs of social and economic development in China. ${ }^{14}$

\section{RESEARCH METHOD}

To have a comprehensive idea of the librarian training programs, the authors reviewed program materials written between 2010 and 2012. In addition, by using research methodologies such as literature review, expert consultation, case analysis, and comparative research, they decided upon the design objectives, training content, training approaches, and testing methods.

To motivate the learners and enhance the training effects, the test methods needed to be considered carefully. By referring to effective testing methods from relevant librarian training programs and asking the instructors and learners for advice, the program working group members employed both qualitative and quantitative test methods. Taking the learning effectiveness, practical training effects, and the two kinds of test methods into account, they eventually formulated and presented a "quaternary test," namely, a test that is made up of four parts:

- Class participation (graded by the classroom teachers, accounting for 15 percent of the final marks): covering students' class performance and participation in analysis and discussions

- Class assignments (graded by the classroom teachers, accounting for 15 percent of the final marks): including course reports, case analysis, scene simulation, scheme planning, and on-the-spot drills

- Learning summary (graded by the teaching group, accounting for 30 percent of the final marks): covering what the trainees have learned from the training and their responses to and suggestions for the training

- Practice reports (graded by experts invited by CALIS, accounting for 40 percent of the final marks): including 
practice reports, case studies and application accomplishment originating from the learners' practical subject service work

Following the training, Certificates of Completion are awarded to those trainees who have passed all the tests concerning class performance, class homework, and a learning summary. The CALIS Phase III Subject Librarian Training Program will choose excellent learners from the qualified participants. In the end, the program will also select outstanding subject librarians and issue them with award certificates.

\section{DESIGN OF THE SUBJECT LIBRARIAN TRAINING SYSTEM}

In designing a subject librarian training program, considerations should extend beyond the competencies mentioned above by librarians at George Mason University Library. For example, the training system needs to be connected with the practical work so that the training will be more systematic and meet the trainees' needs for practical techniques. Therefore, the CALIS Subject Librarian Training Program attaches great importance to preparation work such as investigation of liaisons' training needs, literature surveys, consultation with relevant experts, studying the experiences of foreign libraries and so on.

In the initial stage of designing the training system, the program members did the following pre-research work. First, the CALIS management center conducted literature surveys and expert surveys to explore the overall design of the librarian training systems (courses, forms, contents, etc.). Second, representatives from the CALIS management center visited the University of Auckland Library (in New Zealand) to get systematic and comprehensive knowledge about the design and implementation of librarian training systems in overseas libraries and to learn from their successful experience. Third, Shanghai Jiao Tong University Library, the responsible unit, arranged the organizational measures-training session planning, personnel deployment, execution, and fulfillment-to insure the training effectiveness. After holding two preparation meetings for the training course teachers and dozens of various preparation work meetings, the library worked up the "execution scheme" and "management scheme" respectively. It was after thorough consideration, repeated reasoning, and dozens of revisions that a mature subject librarian training system finally came into being. Specifically, the training system consists of five parts: training objectives, training methods, training sessions, test approaches, and organization and management mechanisms.

\section{Training Objectives}

Goals of the CALIS subject librarian training include the following:
- The learners will have comprehensive knowledge about basic theories, skills, and practice of subject services. They will improve their theoretical knowledge and abilities to formulate plans so that they will become professional liaisons for university libraries in China.

- The learners will master methods for user research, user demand analysis, subject service standards, evaluation strategies design user-targeted services, develop subject resources scientifically and reasonably, have a good command of practical techniques for information literacy education, and carry out different kinds of subject services to support teaching and research in universities and colleges.

- The learners will be able to apply the learned ideas, methods, and tools to their practical work, promote the library subject services, and further increase new values and functions of university libraries.

- The subject service team members will be able to improve their teamwork consciousness and capabilities, strengthen their positive attitudes towards work and increase their professional responsibilities and sense of mission.

\section{Training Methods}

The CALIS Phase III Subject Librarian Training Program focuses on "competency development". For this reason, the instructors from both home and abroad are all experienced subject service experts with respected achievements in subject service research and practice. Adopting open, vivid, and flexible training approaches, these professional teachers impart both the theoretical and practical knowledge of subject services to the students, using a variety of approaches:

- Theory teaching: The instructors center the teaching on a special topic in a thorough and systematic way.

- Classroom discussions: The instructors carry out communication and discussions on certain problems between teachers and students and among students.

- Case analysis: The instructors ask students to discuss a specific case. Through research and discussions, the learners will not only reach common ground but improve their learning and thinking skills.

- Case demonstrations: With the instructors dissecting the subject service system of a certain library with vivid and specific cases, the learners will be able to have a comprehensive understanding of subject service planning, system construction, implementation strategies, etc.

- Operation demonstrations: The instructors demonstrate the operational process while teaching how to use the systematic tools for subject service, subject information analysis devices, office automation software, and so on so that the learners will be able to learn relevant skills directly.

- Role playing: The instructors devise a scene and the learners take a role in the scene to deal with problems designed previously in order that the learners will be able to acquire the experience to handle relevant issues. 


\section{FEATURE}

- Group discussions: After group discussion of questions raised by teachers, learners are required to sum up what they have discussed and give a report on their discussions in front of the class.

- Interactive learning: The learners present problems they have encountered in subject services and the instructors organize discussions about solution to the problems.

- Preparing and discussing: In order to save time and enhance effectiveness of the training, the learners will be assigned to prepare for some of the course content after class, while the teachers will answer questions raised by the students in class and discuss related questions with them.

Whatever approaches are used, the training emphasizes interaction, communication, the combination of instruction and practice, and blending of theory and practice. Simultaneously, by virtue of the distance education platform built by the program management group, virtual classrooms for dispersed teaching and network space for communication between teachers and students are available. This platform supports synchronized video teaching, long-distance interactive multi-media learning, etc. In addition, via integrating various web 2.0 tools, the platform sustains exchanges and interaction between learners and instructors, encourages librarians' autonomous learning, and allows sharing files and uploading homework. The platform thereby builds a network-based learning and communicative community so that the trained librarians will be able to increase their perceptual knowledge of subject services, be inspired in their enthusiasm and creativity at work, and be able to master the subject service ideas, patterns, practical methods, and practical skills.

\section{Training Content}

The training content focuses on practical demand for carrying out subject services in order that the trained librarians will have a command of relevant ideas, knowledge, and techniques. After the librarians have successfully absorbed the course design and training approaches of the program, they are ready to pursue the practical aspects of the course itself. The training is divided into six modules and ten representative courses. These courses completely cover subject service-related theories, basic practical work, user research, services marketing, organization and management, standards and evaluation, information literacy education, research support services, technical instruments and methods, etc. (see table 1).

- After work in module 1, basic theories of and practical approaches to subject services, the trainees will understand the historical development of subject services, the development of new subject service models, and connotation of the new models; be able to organize, manage, plan, design, and build teams for the subject services; and master relevant methods and skills for marketing subject services, studying and analyzing users, and communicating with them.

- After module 2, subject services supporting scientific research, the learners will have a command of tools and methods for analyzing subject development trends, procedures, and standards as well as methods for writing special topic literature survey reports. They will also understand approaches to integrate subject services into the research process in the academic environment.

- After learning module 3, subject services embedded in teaching, the trainees will master methods and models for carrying out information literacy education, information literacy course planning, information literacy course cases, standards, assessment methods, and related resources for information literacy education.

- After module 4, subject collection development, the learners will understand the basic theories of subject resource development, subject resource planning methods, subject resource analysis and assessment methods, approaches to compile subject resource guides, and principles and techniques for subject-specific collection development.

- After learning module 5, techniques related to subject services, the trainees will have a command of techniques germane to subject services, improve their practical abilities and learn relevant skills for broadening and deepening subject services.

- Finally, after module 6, case presentation of subject services, the learners will have intuitive recognition of the subject service work and improve their practical abilities through case viewing, analyzing, and discussing.

Meanwhile, considering that the subject librarians have dissimilar specialties and characteristics, and that it is unnecessary for them to master all the relevant knowledge or have the same knowledge structure as others, the program combines modularized and systematic training content flexibly and carries it out at different stages according to practical needs of the subject specialty, despite the fact that the work of subject services requires rich knowledge and involves multiple disciplines. The learners can thus obtain the Certificates of Completion only if they have finished studying designated modules and have reached required standards.

\section{Organization and Management Mechanism}

To guarantee the standardization and effectiveness of the subject librarian training, the program management group appoints organizers for the training according to the training requirements. After submitting the "Enforcement Schemes and Plans for the CALIS Phase III Subject Librarian Training Program" which are examined and approved by the program management group and authorized by the CALIS management center, the organizers implement the training (see fig. 1).The project management group communicates and coordinates with the organizers, and offers them guidance and standards for 
Table 1. Training Courses of CALIS Subject Librarian Training Program Phase III

\section{Modules}

1. Introduction to and practical basis for subject services

2. Subject services supporting scientific research

\section{Topics and contents}

(1) Basic theories: significances of and strategic thinking for subject services; history and current state of subject services; major modes of subject services; connotation, denotation and future development of subject services in new situations

(2) Top-level design, management and planning for subject services: management \& planning, organization \& assessment, team building, etc., of subject services

(3) Basic and practical approaches: fundamental procedures and methods for developing activities for schools and departments; standards, strategies and techniques for communicating with college faculty and students; cases of subject service marketing and popularization

The construction of knowledge environment for subject services (including institutional repositories and subject information portals); tracking and analysis methods for subject strategic information; analysis approaches, tools and cases for subject development trends; case presentations of integrating subject services into the research process

3. Subject services embedded in teaching

Models, case presentations, and effective evaluation of information literacy; information literacy course system programming and resource sharing; information literacy education and its standards; patterns for carrying out information literacy education and corresponding case demonstrations; information literacy education models and Allan Bloom's educational theories
4. Subject resource development

Basic theoretical methods for subject resource development; subject resource development process and budget collocations; methods for subject resource development planning; current state analysis and assessment of subject resources; evaluating user demand for subject resources; methods for compiling subject resource guides; principles and methods for subject-specific collection development

(1) Technology related to subject services:

5. Techniques germane to subject services

6. Case presentation of subject services construction of the subject service platform management and maintenance of the interactive community for subject services; technological application of personalized subject services

(2) Integrated skills for subject services:

Foreign languages used in subject services (English, Japanese, German, etc.); practical capabilities required for subject services; office automation software frequently used in subject services and file specifications for subject services

Case presentations and discussions of subject services in university libraries; viewing special and individual real cases

\section{Objectives}

The trainees will know about the historical development of subject services, background to the development of new subject service models, and connotation of the new models

The trainees will be able to organize, manage, plan, design, and build teams for the subject services

The trainees will master relevant methods and skills for marketing subject services, studying and analyzing users, and communicating with them.

The trainees will have a good command of tools and methods for analyzing subject development trends, procedures, standards, and methods for writing special topic literature survey reports, and approaches to integrate subject services into the research process in the new academic environment.

The trainees will have a good command of methods and models for carrying out information literacy education, information literacy course planning, information literacy course cases, standards, assessment methods, and related resources for information literacy education.

The trainees will know about basic theories of subject resource development, subject resource planning methods, subject resource analysis and assessment methods, approaches to compile subject resource guides, and principles and techniques for subjectspecific collection development.

The trainees will know about or have a good command of techniques related to subject services, improve their practical abilities and learn relevant skills for broadening and deepening subject services.
The trainees will have intuitive recognition of the subject service work and improve their practical abilities through case viewing, analyzing, and discussing. 


\section{FEATURE}

carrying out the training according to the requirements of the CALIS management center and program management schemes of the subject librarian training program.

Other specific management approaches include:

- The document entitled "Responsibilities for the Training Organizers" clarifies the organizers duties and responsibilities, guaranteeing the systematic implementation, quality, and effectiveness of the training.

- On the basis of "Aptitude Requirements for Librarian Training Course Teachers," noted experts on library and information science both at home and abroad are invited. Outstanding and professional librarians with many years of research and practical experience in subject services comprise the teaching groups who attend teaching work meetings in order to know about the training requirements. At the same time, the tri-level teaching group, i.e., head teachers, training course teachers, and teaching assistants, is set up to offer a guarantee of quality for the teaching.

- To guarantee the training quality, the organizers, together with the CALIS management center and the program management group, adopt multiple guarantee measures in order that the research and studies can be timely and successfully completed.

- To insure success of the subject librarian training, a series of pertinent management files are formed, including: Students' Manuals, Teachers' Manuals, curriculum schedules, registration forms for learners' personal information, group lists for learners, homework topics for group research and discussions, plans for interactive teaching and communication, registration forms for learners' performance, students' learning summaries, and survey questionnaires for the training.

\section{FINDINGS}

\section{Implementation Overview}

The program management group divides the subject librarian training program into three stages, i.e., preparation stage, implementation stage, and conclusion stage, in order that the organizer can plan, organize, and implement the training according to different features of the three training stages. In the preparation stage, the organizer should be aware of his or her roles and responsibilities, formulate implementation schemes and plans for the training, contact and arrange teachers for the training courses, carry out necessary preparation work, and submit relevant documents to the program management group to examine and revise. In the implementation stage, the organizer should be responsible for the organization, management, and implementation of the subject librarian training, and for insuring that the training is completed. In the conclusion stage, the organizer needs to summarize the training implementation and keep track of the training effects, collect relevant suggestions, and hand in the summary reports and

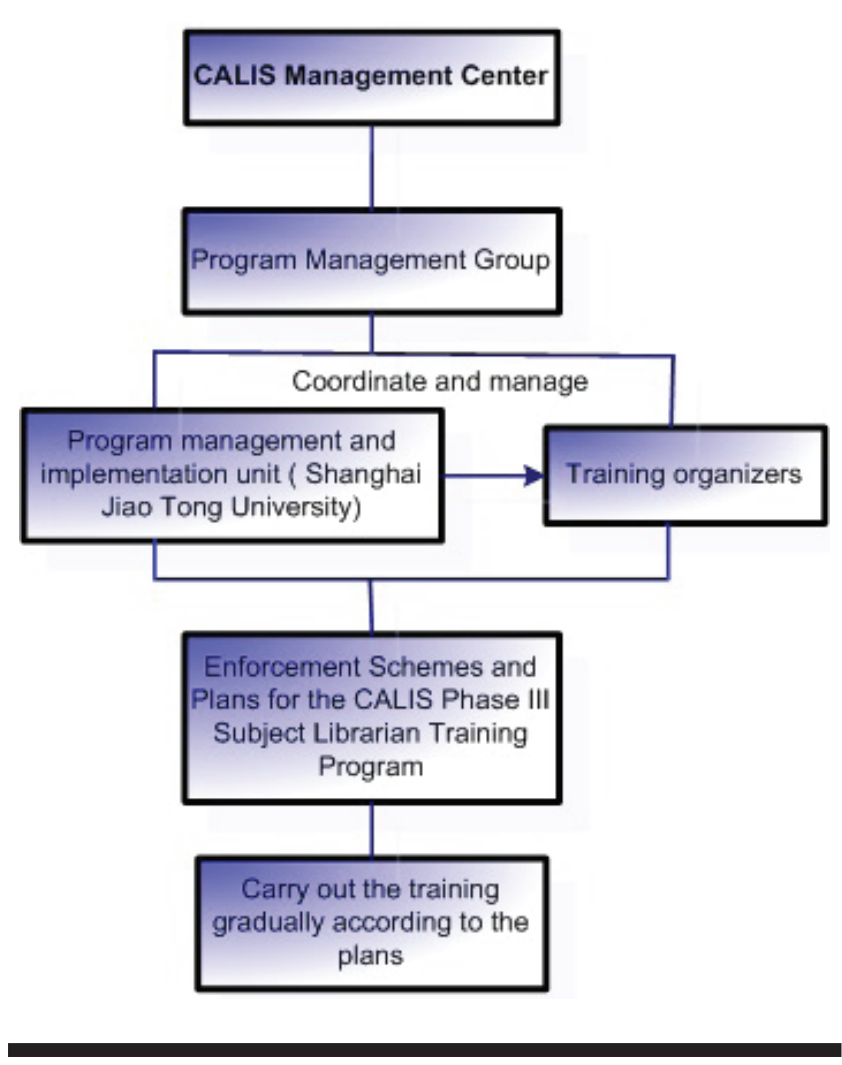

Figure 1. Management Procedures for the Subject Librarian Training

relevant documents as well as archive them so as to accumulate experience for later training courses.

From November 2010 to March 2012, Shanghai Jiao Tong University Library, Library of University of Electronic Science and Technology of China, Xian Jiao Tong University Library, Northwest Agriculture and Forestry University Library, Xiamen University Library, and Yanshan University Library held five phases of the liaison librarian training respectively and trained 322 liaisons for 197 universities in China (see table 2). The training system is so standard and rigorous that it is called the "Huangpu Military Academy" (a new type of school for the revolutionary military officers set up in 1924 by Sun Yat-sen, the leader of China's republican revolution) for subject librarians.

At the end of the program, i.e., in early April 2012, a seminar about case sharing and communication between representative teachers and learners from the subject librarian training courses was held in Wuhan. In the seminar, the students shared 82 subject service cases which they summarized in practice after the training program, and teachers and experts made comments on the cases. In the future, these service cases will be included in a book, as yet to be published, aiming to provide more reference for future subject specialist librarians.

\section{Major Characteristics}

The CALIS Subject Librarian Training Phase III has many characteristics. For instance, the organizers make elaborate 
Table 2. Overview of Five Phases of the Subject Librarian Training Program

\begin{tabular}{|c|c|c|c|c|c|}
\hline Phases & =Timespan & Cities & Organizers & $\begin{array}{l}\text { Students } \\
\text { Registered }\end{array}$ & $\begin{array}{l}\text { Universities } \\
\text { Covered }\end{array}$ \\
\hline 1 & Nov. 21-Nov. 26, 2010 & Shanghai & Shanghai Jiao Tong University Library & 62 & 34 \\
\hline 2 & June 14-June 18, 2011 & Chengdu & $\begin{array}{l}\text { Library of University of Electronic Science and } \\
\text { Technology of China }\end{array}$ & 60 & 47 \\
\hline 3 & Oct. 17-Oct. 22, 2011 & Xian & $\begin{array}{l}\text { Xian Jiao Tong University Library, Northwest } \\
\text { Agriculture and Forestry University Library }\end{array}$ & 63 & 46 \\
\hline 4 & Dec. 5-Dec. 10, 2011 & Xiamen & Xiamen University Library & 60 & 42 \\
\hline 5 & Mar. 12-Mar. 17, 2012 & Qinhuangdao & Yanshan University Library & 79 & 70 \\
\hline
\end{tabular}

preparations; the teachers carefully plan the lessons and give good instructions; the training contents are systematic and practical; the learners are expected to work hard and do thorough research; the interaction and communication between teachers and students should be effective and so on. According to statistics of a satisfaction degree survey for the CALIS III Subject Librarian Literacy Training, the learners' average degree of satisfaction with each training course reaches 97 percent, suggesting that the training achieves its goals. Generally speaking, the training displays the following features which are key elements to insure effectiveness of the training.

\section{Emphasis by the Management Center, Management Group, and Organizers, and Support of University Librarians}

With the concept of "sharing," the CALIS management center attaches great importance to the program so that favorable policies are formulated for and enough funding is made available to the program. The program management group and the organizers make careful deployment and thorough arrangements for the training content design, personnel allocation and training implementation, reflecting the collective spirit and good cultural atmosphere. Furthermore, university librarians give strong support to the program by actively entering their names in application for the program.

\section{Practical Courses with a Focus on Competency Cultivation}

Focusing on cultivating advanced concepts and practical techniques for the subject librarians, the training sessions systematically and comprehensively cover the subject servicerelated ideological systems and basic practical work, including user study, service advocacy, organization and management, standardization and evaluation, information literacy education, scientific research support services, and technical tools and methods. Learners generally hold that the teaching system is standard and complete and the training content is practical. The training, which lays emphasis on ability construction, abandons the traditional cramming methods of teaching and uses such teaching models as group discussions, case viewing, scene drilling, peer reviews, and interaction between teachers and students, which are all welcomed by and popular with the learners. In the first phase of the program, for example, the training carried out such activities as "Living Library-Interactive Salons for Instructors and Learners," information literacy education case viewing and discussions, case demonstrations of scientific research support services, "case drilling and assignment comments" and an "Art Exhibition by the Media and Design School." Altogether, more than 30 interactive activities and 20 research topics were available in the training sessions, displaying subject service cases in an all-around way and providing the learners platforms for demonstrating, sharing, communicating, researching, and discussing

\section{Careful Program Preparation and Three-Dimensional Guarantee}

Each phase of the subject librarian training is carefully planned and prepared, including the following:

- compiling and designing the teaching programs and templates, and working out standards and requirements

- organizing and editing training textbooks and lecture manuscripts

- formulating and printing Students' Manuals and Teachers' Manuals

- appointing two head teachers for the training courses

- appointing relevant workers to guarantee the daily traffic flow and room and board

Additionally, the implementation of the training is closely related to having a robust technical support system in place. In the first phase, for instance, training rooms with synchronized broadcasts were applied to insure the training effectiveness. In the second phase, the live audio was available in branch training rooms. The CALIS subject librarian training program set up special websites, designed special columns 


\section{FEATURE}

based on the course modules, established online discussion sections, QQ groups, FTP file sharing, online PowerPoint, and instructional videos so that the trainees were able to keep communicating with each other after the training is finished. The opportunity is also provided for other librarians interested in the training to learn online by themselves.

\section{Standard, Diversified, and Practical Training}

To insure that the training program deserves the name "Huangpu Military Academy" for subject librarians, the training system has strict requirements, a tight schedule, and standardized implementation requirements. In each class, there is a registration form for "Class Performance of Learners" recorded by the teaching assistants. At the end of each training session, the learners hand in a "summary of learning." What is more, to motivate the learners, "Case Drilling and Viewing," "Assignment Feedback Form," "Survey Questionnaires of Learners' Satisfaction Degree," are designed to record learners' performance and collect their suggestions.

In addition, the training program adopts a number of case teaching methods closely connected with subject services. Many teachers further offer relevant and valuable professional templates which have lots of reference value. According to incomplete statistics, case teaching in various training courses amounts to 30 times the value of non-case teaching. The case teaching is very effective, just as Denghui Kuang from Nankai University Library commented: "We can not only learn the wisdom and ideas from each training course teacher but also learn from the exemplary persons beside us through vivid case demonstration." Many learners said that they had learned a great deal through studying cases. Some of them even drew up "work plans" and prepared to apply what they had learned to the practical work of subject services. Simultaneously, all sorts of interactive discussions, research, and communication greatly promoted the experiences of collaboration, information sharing, mutual encouragement, and common development.

The CALIS management center and program management group has made great contribution to the librarian training program. In addition to the completion certificates for subject librarians issued by the CALIS management center, there is still another "Completion Certificate of Advanced Training Courses for Young and Core University Teachers" awarded by the Human Resource Division and Higher Education Division of the Ministry of Education of the People's Republic of China (PRC), which indicates that the subject librarian training is approved and supported by the Ministry of Education of the PRC, and it is striding towards standardization, normalization, and internationalization.

\section{CONCLUSION}

The CALIS Subject Librarian Training Program is the first of its kind in China. It set up a specialized project team and formed a relatively complete set of management implementation standards which provide reference for other subject librarian training. When designing the curriculum and training methods, the program directors, managers, and organizers learned from experiences at home and abroad in terms of professional qualification systems for librarians. Altogether, they planned six teaching modules and ten representative courses which comprehensively and systematically covered theory and basic practices related to subject services, e.g., user research and service marketing, organizational management and standardized evaluation, information literacy education, subject services supporting scientific research, and subject service related technology. In addition to giving lessons, the training also includes rich and novel class practice such as "case studying and homework commenting" in groups, subject service case presentation and observation, more than thirty interactive procedures, and more than twenty seminar topics incorporated in the courses, adequately providing students with a sharing, communication, and discussion platform. On account of the varied and practical teaching content and adherence to the principle of making study serve the practical purpose, students are quite satisfied with the training. Statistics of online questionnaires show that the satisfaction degree of trainees from the five training programs is up to 97.85 percent.

Moreover, the program directors, managers, and organizers prepared complete teaching management documents. They printed two sets of learning materials for the students, "Textbook Collections for Subject Librarian Training" and "Lecture Notes Collections for Subject Librarian Training," and summarized student feedback, practice reports, and service cases which offered sufficient and necessary materials to subject service work research and study. Besides, they edited a series of teaching management documents, including the "Learners' Handbook," "Teachers' Manual," curriculum schedule, registration forms of students' personal information, lists of learners' grouping, topics for group discussion, plans for interactive teaching activities, registration forms of students' performance, students' learning summary, and questionnaires for the training.

Finally, the program attached great importance to marketing. The working group members printed relevant promotional materials, including eight issues of carefully designed color pages of "CALIS Work News" with content to promote the training. A specialized website has been established to provide timely reporting about the training. Also, the working group members actively invited relevant media to report about the program to increase its visibility and effectiveness. Furthermore, the program stressed survey and feedback of teachers, and students, so as to immediately summarize relevant circumstances and to constantly adjust and improve the training.

The subject service librarianship is highly creative. Through subject librarians' services, a truly user-oriented library service system can be established, promoting a serviceoriented professional restructuring. Therefore, the subject 
librarians are expected to have strong competencies. ${ }^{15}$ With the roles of subject librarians changing, the English scholar Stephen Pinfield notes that there are more competency requirements for the subject librarians concerning such aspects as professional subject knowledge, interpersonal communication skills, communicative abilities, IT skills, teaching and expression abilities, budget management techniques, analysis and evaluation capabilities, teamwork and team building capabilities, project management competencies, quick learning abilities, flexibility, and imagination. ${ }^{16}$ Accordingly, training for subject librarians needs to be regular, systematic, and conducted in accordance with the subject librarian qualification certification guidelines.

The work of Subject Librarian Information Literacy Training and Qualification Certification started by the CALIS Management Center in the third phase has proven both popular and effective. The CALIS Phase III Subject Librarian Training Program is of great significance, as evidenced by what a learner named Wenlan Li, a librarian from Tianjin University Library, said after having completed the training courses, "I firmly believe that the trainees of the CALIS training courses will become 'kindling' for the library subject services in China and light the fire of subject innovation in higher education within the country!"

\section{References}

1. Yingqi Tang and Zhiping Xia, "A Study of Subject Service in Chinese Academic Libraries," CALA Occasional Paper Series no. 7 (November 2010): 1-6.

2. B. Chawner and G. Oliver, "A Survey of New Zealand Academic Reference Librarians: Current and Future Skills and Competencies," Australian Academic \& Research Libraries 44, no. 1 (2013): 29-39.
3. George Mason University Library, "Liaison Librarian Program: Liaison Competencies," accessed June 9, 2013, http://eprints.not tingham.ac.uk/archive/00000033/03/jolos.pdf.

4. M. J. Krasulski, "Where do They Come From, and How are They Trained? Professional Education and Training of Access Services Librarians in Academic Libraries," Journal of Access Services 11, no. 1 (2014): 14-29.

5. L. Luo, "Professional Preparation for 'Text a Librarian': What are the Requisite Competencies?" Reference \& User Services Quarterly 52, no. 1 (2012): 44-52.

6. M. Cassella and M. Morando, "Fostering New Roles for Librarians: Skills Set for Repository Managers-Results of a Survey in Italy," LIBER Quarterly 21, no. 3-4 (2012): 407-28.

7. L. Todorinova and M. Torrence, "Implementing and Assessing Library Reference Training Programs," Reference Librarian 55, no. 1 (2014): 37-48.

8. Tang and Xia, "A Study of Subject Service."

9. Su Chen and Jing Liu, "Using Libraries in China: Know before You Go," College \& Research Libraries News 66, no. 2 (2005): 124-25, 30.

10. Jianzhong Wu and Huang Ruhua, "The Academic Library Development in China," Journal of Academic Librarianship 29, no. 4 (2003): 249-53.

11. J. Guo et al., "Effectiveness Analysis of CALIS III Subject Librarian Literacy Training," Library Management 34, no. 2 (2013): 372-84.

12. Hannelore B. Rader, "Information Literacy and Academic Libraries in China: Report of A Recent Visit," Library Hi Tech News 19, no. 4 (2002): 3-4.

13. Hongwei Yuan, "On the Status-quo of the Subject Librarian Team Construction in Some Domestic College Libraries," Library \& Information Service no. 51 (2007): 96-68.

14. Ying Shen, "Chinese Academic Librarianship in Transition: A Comparative Study between China and the United States," International Information \& Library Review 38, no. 2 (2006): 89-100.

15. Jingli Chu and Dongrong Zhang, "Subject Librarian 2.0 and Subject Services," Library \& Information Service 52, no. 2 (2008): 6-8.

16. Stephen Pinfield, "The Changing Role of Subject Librarians in Academic Libraries," Journal of Librarianship \& Information Science 33, no. 1 (2001): 32-38. 